\title{
Relationship Between Rate of Digestion of Foods and Post-Prandial Glycaemia
}

\author{
D.J.A. Jenkins ${ }^{1}$, H. Ghafari ${ }^{2}$, T. M.S. Wolever ${ }^{1}$, R. H. Taylor ${ }^{3}$, A. L. Jenkins ${ }^{1}$, H. M. Barker ${ }^{3}$, H. Fielden ${ }^{3}$ \\ and A.C. Bowling ${ }^{2}$ \\ ${ }^{1}$ Department of Nutritional Sciences, Faculty of Medicine, University of Toronto, Canada, ${ }^{2}$ University Laboratory of Physiology, Oxford \\ and ${ }^{3}$ Department of Gastroenterology and Nutrition, Central Middlesex Hospital, London, UK
}

Summary. The amount of carbohydrate released at 1 and $5 \mathrm{~h}$ by digestion in vitro of $2 \mathrm{~g}$ carbohydrate portions of 14 foods by human digestive juices was compared with the area under the 2-h blood glucose response curve when $50 \mathrm{~g}$ carbohydrate portions were fed to groups of five to ten healthy volunteers. A significant relationship was found between the amounts of sugars and oligosaccharides liberated at 1 and $5 \mathrm{~h}$ and the food blood glucose area expressed as a percentage of the blood glucose area for $50 \mathrm{~g}$ glucose $(r=0.8627$ and $0.8618, p<0.001)$. A significant relationship was also found between the glycaemic index and the food fibre content $(p<0.02)$ and between the glycaemic index and the glucose trapping capacity of the foods $(p<0.05)$. Legumes as a group liberated $56 \%$ less sugars and oligosaccharides $(p<0.01)$ than the eight cereal foods over $5 \mathrm{~h}$. It is suggested that such studies in vitro may help to identify food of use for diabetic patients, and at the same time throw further light on factors which affect post-prandial glycaemia.

Key words: Digestion in vitro, post-prandial glycaemia, rate of absorption, dietary fibre, dietary carbohydrate, diabetes.

The possibility that diabetic control might be improved by altering either the nature or the amount of carbohydrate foods eaten has received considerable attention [1-6]. Much of the experimental work has focussed on differences in the nature of the starch source [7] or the effects of altering the fibre content of the food [8-10].

It has been suggested that the improvement in meal tolerance and diabetic control results from a reduction in the rate of carbohydrate absorption $[5,9]$. Initial studies with viscous forms of dietary fibre sug- gested that this may be a consequence of delayed gastric emptying $[11,12]$. However, recent preliminary studies involving digestion in vitro of three foods demonstrated that the two which raised the blood glucose levels least after feeding in normal or diabetic volunteers were those which released their carbohydrate products most slowly on incubation with human digestive juices [13].

To see whether the rate of digestion correlated with the post-prandial blood glucose levels after eating, a wider range of foods $(n=14)$ were selected from those previously tested in normal volunteers [14]. The rate at which they released their products of digestion in vitro was compared with the degree to which they raised the blood glucose level of normal volunteers.

\section{Methods}

\section{Testing in Vitro}

Carbohydrate portions $(50 \mathrm{~g})[16,17]$ of instant mashed potatoes (Winfield, WH Woolworth, London), sweet potatoes, white and brown rice, white and wholemeal spaghetti, buckwheat, millet, oats, kidney beans, soya beans, lentils and marrowfat peas were cooked by boiling in a minimum of water with $2 \mathrm{~g}$ salt.

Carbohydrate equivalents of each food $(2 \mathrm{~g})$, ground to a smooth paste in a pestle and mortar, and finely crumbed wholemeal bread were mixed separately with $2.5 \mathrm{ml}$ of fresh pooled human saliva. To this was added $7.5 \mathrm{ml}$ of pooled human post-prandial jejunal juice obtained from individuals with normal pancreatic function (Lundh test aspirates with mean tryptic activity > $15 \mathrm{IU} / \mathrm{l}$ ) which had been aliquoted and stored at $-20^{\circ} \mathrm{C}$.

To ensure that the final volume of each food-enzyme mixture was the same, the volumes were adjusted to $30 \mathrm{ml}$ by addition of distilled water. This figure was chosen since it was the volume of the soya beans with $10 \mathrm{ml}$ of digestive enzymes added. The mixtures were stirred well and placed in dialysis bags made of $13 \mathrm{~cm}$ strips of dialysis tubing (Visking' size 9-36/32", Medicell International, London). Each bag was suspended in separate stirred water baths containing $800 \mathrm{ml}$ distilled water at $37^{\circ} \mathrm{C}$. Aliquots of dialysate 
Table 1. Composition of test meals

\begin{tabular}{|c|c|c|c|c|c|c|}
\hline Meal & $\begin{array}{l}\text { Uncooked } \\
\text { weight }(\mathrm{g})\end{array}$ & $\begin{array}{l}\text { Total meal } \\
\text { volume }(\mathrm{ml})\end{array}$ & $\begin{array}{l}\text { Carbohydrate } \\
\text { (g/meal) }\end{array}$ & $\begin{array}{l}\text { Fat }^{\mathrm{a}} \\
\text { (g/meal) }\end{array}$ & $\begin{array}{l}\text { Protein }^{a} \\
(\mathrm{~g} / \text { meal })\end{array}$ & $\begin{array}{l}\text { \% Carbo- } \\
\text { hydrate } \\
\text { as sugar }\end{array}$ \\
\hline Lentils & 94 & 714 & 50 & 1.0 & 22.0 & 4.6 \\
\hline Soya beans ${ }^{b}$ & 250 & 1220 & 50 & 45.0 & 87.5 & 56.0 \\
\hline Marrow fat peas & 100 & 850 & 50 & 1.3 & 21.6 & 4.8 \\
\hline Kidney beans & 111 & 881 & 50 & 1.1 & 24.5 & 6.6 \\
\hline Wholemeal bread & 120 & 640 & 50 & 3.2 & 10.5 & 5.0 \\
\hline Instant mashed potatoes ${ }^{\mathrm{c}}$ & 62 & 662 & 50 & 0 & 4.4 & 2.8 \\
\hline White rice & 60 & 830 & 50 & 0.6 & 3.9 & 0 \\
\hline Brown rice & 62.3 & 832 & 50 & 0.4 & 4.9 & 0 \\
\hline White spaghetti & 60 & 830 & 50 & 0.6 & 8.2 & 3.0 \\
\hline Wholemeal spaghetti & 71 & 841 & 50 & 3.5 & 9.7 & 6.0 \\
\hline Sweet potato & 233 & 688 & 50 & 1.3 & 2.8 & 45.2 \\
\hline Buckwheat $^{\mathrm{b}}$ & 70 & 670 & 50 & 1.4 & 7.7 & 0 \\
\hline Millet $^{\mathrm{b}}$ & 68 & 668 & 50 & 1.7 & 6.8 & 0 \\
\hline Porridge oats & 69 & 769 & 50 & 6.0 & 8.6 & 0 \\
\hline
\end{tabular}

a Excluding milk $(50 \mathrm{ml}=2.4 \mathrm{~g}$ carbohydrate, $1.9 \mathrm{~g}$ fat, $1.6 \mathrm{~g}$ protein) taken with all meals, milk ( $300 \mathrm{ml}=14.4 \mathrm{~g}$ carbohydrate, $11.4 \mathrm{~g}$ fat, $9.6 \mathrm{~g}$ protein) taken with porridge oats, and skinned and pipped tomato $(120 \mathrm{~g}=3.4 \mathrm{~g}$ carbohydrate, trace of fat and $1.1 \mathrm{~g}$ protein) taken with lentils, soya, kidney beans, bread, rice, spaghetti, buckwheat and millet $[16,17]$

b Values from Platt [17]

c Winfield brand, WH Woolworth, London, UK

Table 2. Mean concentrations of glucose and total carbohydrate measured as glucose in the dialysate after 1 and $5 \mathrm{~h}$ incubation: pooled data on 14 foods

\begin{tabular}{|c|c|c|c|c|}
\hline & \multicolumn{4}{|c|}{$\begin{array}{l}\text { Carbohydrate concentration in dialysate } \\
(\mathrm{mmol} / \mathrm{l})\end{array}$} \\
\hline & \multicolumn{2}{|c|}{$\begin{array}{l}\text { Glucose } \\
\text { (Pre-hydrolysis) }\end{array}$} & \multicolumn{2}{|c|}{$\begin{array}{l}\text { Total glucose } \\
\text { (Post-hydrolysis) }\end{array}$} \\
\hline & $1 \mathrm{~h}$ & $5 \mathrm{~h}$ & $1 \mathrm{~h}$ & $5 \mathrm{~h}$ \\
\hline $\begin{array}{l}\text { Food and digestive } \\
\text { juice minus digestive } \\
\text { juice alone }\end{array}$ & -0.15 & 0.46 & 0.88 & 3.91 \\
\hline $\begin{array}{l}\text { Food and digestive } \\
\text { juice minus food and } \\
\text { boiled digestive juice }\end{array}$ & 0.13 & 1.01 & 0.93 & 4.12 \\
\hline
\end{tabular}

were taken at 1 and $5 \mathrm{~h}$ for analysis of glucose, maltose and oligosaccharides. Glucose was analysed by a standard enzymatic technique [15]. Maltose and oligosaccharides were analysed together as glucose after acid hydrolysis with a half volume of $10 \mathrm{~mol} / 1 \mathrm{HCl}$ for $2 \mathrm{~h}$ at $75^{\circ} \mathrm{C}$ followed by neutralisation with $\mathrm{NaOH}$. We have shown that after this treatment, $97 \%$ of a $5 \mathrm{mmol} / 1$ maltose solution could be accounted for as glucose.

Tests on instant mashed potatoes, soya beans, lentils and wholemeal bread were repeated on six separate occasions and the means taken. The other foods were tested on a single occasion in batches of five and an additional potato test was also run with each batch to ensure that there was no inter-batch variation.

Further tests were undertaken with all foods using saliva and jejunal juice after inactivation of the digestive enzymes by boiling so that allowance could be made for free sugars already in the foods or the Lundh juice. Results are given for free glucose and total sugars and oligosaccharides, i. e. maltose, maltotriose and $\propto$-limit dextrins, measured as glucose after acid hydrolysis, which were liberated into the dialysate during the digestion of the foods in vitro.

In this series, when the digestive juices alone were added to the water in the dialysis bags, the mean 1 and $5 \mathrm{~h}$ dialysate values were: pre-hydrolysis: $0.94 \mathrm{mmol} / \mathrm{l}(1 \mathrm{~h})$ and $1.94 \mathrm{mmol} / 1(5 \mathrm{~h})$ and posthydrolysis: $0.74 \mathrm{mmol} / \mathrm{l}(1 \mathrm{~h})$ and $1.68 \mathrm{mmol} / \mathrm{l}(5 \mathrm{~h})$. The individual figures from which these means were derived were used in calculating the concentration of sugars and oligosaccharides, as glucose, liberated into the dialysate during digestion $(\mathrm{SO})$ :

$\mathrm{SO}=[\mathrm{F}+\mathrm{DJ}]-[\mathrm{DJ}]$

where $[F+D J]$ and $[D J]$ are the concentrations of sugars and oligosaccharides surrounding the dialysis bags containing either food, F, and digestive juice, DJ, or digestive juice alone. This represents the sugars and oligosaccharides liberated from the food both enzymatically and non-enzymatically. The enzymatically liberated component $\mathrm{SO}_{\mathrm{E}}$ was estimated by:

$\mathrm{SO}_{\mathrm{E}}=[\mathrm{F}+\mathrm{DJ}]-\left[\mathrm{F}+\mathrm{DJ}_{\mathrm{B}}\right]$

where $\mathrm{D} \mathbf{J}_{\mathrm{B}}$ is boiled digestive juice.

In addition, $3 \mathrm{mmol}$ of either glucose or maltose was substituted for the enzyme solutions in the dialysis bags to allow the potential trapping of sugars by the foods to be measured. The percentage trapped, $\mathrm{T}$, was measured for both glucose and maltose using the equation:

$\mathrm{T}=100\left(1-\frac{[\mathrm{F}+\mathrm{S}]}{[\mathrm{S}]}\right)$

where $[\mathrm{F}+\mathrm{S}]$ and $[\mathrm{S}]$ are the concentrations of either glucose or maltose surrounding the dialysis bag containing either the sugar solution and the food, $F+S$, or the sugar solution alone, $S$. The proportion trapped together with the value for the carbohydrate liberated into the dialysate by enzymatic digestion allowed the total amount of starch digested to be estimated. 
Table 3. Glucose and maltose trapping by foods and carbohydrate digested at 1 and $5 \mathrm{~h}$ for individual foods

\begin{tabular}{|c|c|c|c|c|c|c|c|}
\hline & \multicolumn{2}{|c|}{$\begin{array}{l}\text { Total carbohydrate concentration } \\
\text { in dialysate }{ }^{\mathrm{a}} \text {, expressed as glucose } \\
(\mathrm{mmol} / \mathrm{l}) \text { at: }\end{array}$} & \multicolumn{2}{|c|}{$\%$ Trapped } & \multicolumn{2}{|c|}{$\begin{array}{l}\% \text { Carbohydrate } \\
\text { digested }\end{array}$} & \multirow{2}{*}{$\begin{array}{l}\text { Dietary } \\
\text { fibre }[16,17] \\
\mathrm{g} / 50 \mathrm{~g} \mathrm{CH}_{2} \mathrm{O}\end{array}$} \\
\hline & $1 \mathrm{~h}$ & $5 \mathrm{~h}$ & Glucose & Maltose & $1 \mathrm{~h}$ & $5 \mathrm{~h}$ & \\
\hline Lentils & 0.23 & 2.59 & 26 & 25 & 4 & 27 & 11.0 \\
\hline Soya beans & -0.20 & -0.02 & 60 & 50 & 1 & 4 & 27.9 \\
\hline Marrowfat peas & 0.70 & 2.84 & 28 & 31 & 9 & 34 & 16.2 \\
\hline Kidney beans & 0.80 & 2.78 & 31 & 35 & 10 & 35 & 27.7 \\
\hline Wholemeal bread & 1.48 & 6.76 & 11 & -11 & 9 & 41 & 10.2 \\
\hline Instant mashed potato & 1.33 & 5.07 & 29 & 28 & 14 & 50 & 10.2 \\
\hline White rice & 1.20 & 4.76 & 18 & 19 & 12 & 45 & 1.4 \\
\hline Brown rice & 1.30 & 5.14 & 28 & 23 & 14 & 53 & 3.5 \\
\hline White spaghetti & 1.00 & 4.96 & 25 & 22 & 12 & 48 & 2.0 \\
\hline Wholemeal spaghetti & 0.72 & 3.66 & 26 & 26 & 9 & 39 & 7.3 \\
\hline Sweet potato & 1.16 & 4.28 & 31 & -49 & 2 & 12 & 5.8 \\
\hline Buckwheat & 1.02 & 3.94 & 15 & 25 & 10 & 41 & 4.9 \\
\hline Millet & 0.94 & 4.60 & 35 & 19 & 10 & 46 & 9.5 \\
\hline Porridge oats & 0.70 & 3.42 & 34 & 17 & 7 & 35 & 4.3 \\
\hline Mean \pm SEM & $0.88 \pm 0.12$ & $3.91 \pm 0.43$ & $28 \pm 3$ & $19 \pm 6$ & $9 \pm 1$ & $36 \pm 4$ & $10.1 \pm 2.3$ \\
\hline
\end{tabular}

a Including free sugars and the products liberated by digestion ( $\mathrm{SO}$ - see equation)

Table 4. Mean area ${ }^{\mathrm{a}}$ under the blood glucose curve for each food tested, the area for the $50 \mathrm{~g}$ GTT taken by the subjects who tested the food and the glycaemic index

\begin{tabular}{|c|c|c|c|c|c|}
\hline \multirow[t]{2}{*}{ Food } & \multirow[t]{2}{*}{$\begin{array}{l}\text { Number } \\
\text { of } \\
\text { Subjects }\end{array}$} & \multicolumn{2}{|c|}{$\begin{array}{l}\text { Mean area under } \\
\text { curve } \\
\left(\mathrm{mmol} \cdot \min 1^{-1}\right)\end{array}$} & \multirow[t]{2}{*}{$\begin{array}{l}\text { Glycaemic } \\
\text { index }\end{array}$} & \multirow[t]{2}{*}{$p^{\mathrm{b}}$} \\
\hline & & Food & Glucose & & \\
\hline Lentils & 7 & $60 \pm 6$ & $213 \pm 21$ & $29 \pm 3$ & $<0.001$ \\
\hline Soya & 7 & $17 \pm 6$ & $188 \pm 18$ & $15 \pm 5$ & $<0.001$ \\
\hline $\begin{array}{l}\text { Marrowfat } \\
\text { peas }\end{array}$ & 6 & $99 \pm 8$ & $212 \pm 18$ & $47 \pm 3$ & $<0.001$ \\
\hline $\begin{array}{l}\text { Kidney } \\
\text { beans }\end{array}$ & 7 & $64 \pm 18$ & $228 \pm 13$ & $29 \pm 8$ & $<0.001$ \\
\hline $\begin{array}{l}\text { Wholemeal } \\
\text { bread }\end{array}$ & 10 & $173 \pm 24$ & $237 \pm 24$ & $72 \pm 6$ & $<0.001$ \\
\hline $\begin{array}{l}\text { Instant } \\
\text { mashed } \\
\text { potato }\end{array}$ & 8 & $138 \pm 18$ & $194 \pm 27$ & $80 \pm 13$ & NS \\
\hline White rice & 7 & $167 \pm 29$ & $228 \pm 24$ & $72 \pm 9$ & $<0.02$ \\
\hline Brown rice & 7 & $150 \pm 18$ & $228 \pm 24$ & $66 \pm 5$ & $<0.001$ \\
\hline $\begin{array}{l}\text { White } \\
\text { spaghetti }\end{array}$ & 6 & $96 \pm 14$ & $193 \pm 14$ & $51 \pm 8$ & $<0.002$ \\
\hline $\begin{array}{l}\text { Wholemeal } \\
\text { spaghetti }\end{array}$ & 6 & $78 \pm 7$ & $193 \pm 14$ & $42 \pm 4$ & $<0.001$ \\
\hline $\begin{array}{l}\text { Sweet } \\
\text { potato }\end{array}$ & 5 & $103 \pm 7$ & $226 \pm 25$ & $48 \pm 6$ & $<0.001$ \\
\hline Buckwheat & 5 & $100 \pm 16$ & $207 \pm 25$ & $51 \pm 11$ & $<0.01$ \\
\hline Millet & 5 & $141 \pm 14$ & $207 \pm 25$ & $71 \pm 10$ & $<0.05$ \\
\hline Oats & 6 & $98 \pm 18$ & $208 \pm 22$ & $49 \pm 8$ & $<0.002$ \\
\hline
\end{tabular}

a Area taken as the rise in blood glucose above the starting value over the $2 \mathrm{~h}$ of the test

b Significance of difference from glucose mean area NS $=$ not significant

\section{Testing in Vivo}

As reported previously [14], groups of five to ten healthy volunteers drawn from a pool of 17 (eight males, nine females; mean age: $28 \pm$ 2 years; mean ideal body weight: $105 \pm 3 \%$ ), took 14 foods in random order after overnight fasts. These were compared with an equivalent amount of carbohydrate taken as glucose. The foods were given as $50 \mathrm{~g}$ carbohydrate portions as calculated from standard food tables [16]. Foods were prepared in an identical fashion to those used for testing in vitro. To increase palatability, all meals included tea made with one tea bag and $50 \mathrm{ml}$ milk so that the total volume of the meal was at least $600 \mathrm{ml}$ (Table 1). The porridge was taken with $300 \mathrm{ml}$ milk. Skinned, pipped tomato $(120 \mathrm{~g})$ was added to the spaghetti, rice, bread, millet, buckwheat and legumes.

At least one $50 \mathrm{~g}$ glucose tolerance test (GTT) was taken by each subject. The glucose was taken in $550 \mathrm{ml}$ tea and $50 \mathrm{ml}$ milk, except for the GTT to be compared with porridge where $50 \mathrm{~g}$ glucose was taken in $250 \mathrm{ml}$ tea and $350 \mathrm{ml}$ milk. Those individuals who tested more than three foods took another $50 \mathrm{~g}$ GTT for every additional three to four foods tested.

Meals and GTT's were taken over 10 or 15 min at set times in the morning after standard activity and meals on the previous day. Finger prick blood samples were obtained with Autolet lancets (Owen Mumford, Woodstock, Oxon, UK) at 0, 15,30, 45, 60,90 and $120 \mathrm{~min}$ from hands warmed between electric blankets to ensure good blood flow. Blood samples were collected into tubes containing $83 \mu \mathrm{g}$ sodium fluoride and $250 \mu \mathrm{g}$ potassium oxalate, and stored on crushed ice or frozen at $-20^{\circ} \mathrm{C}$ before analysis for glucose by a glucose oxidase method (Yellow Springs Instruments, 23AM glucose analyser) [18].

Results are given as mean \pm SEM. The area under the 2 -h glucose curve was expressed as a percentage of the appropriate mean GTT value and defined as the glycaemic index (ie. glycaemic index $=\frac{\text { food glucose area }}{50 \mathrm{~g} \text { GTT glucose area }} \times 100$ ). The significance of the percentage reduction in glucose area for each food was calculated using Student's t-test. 


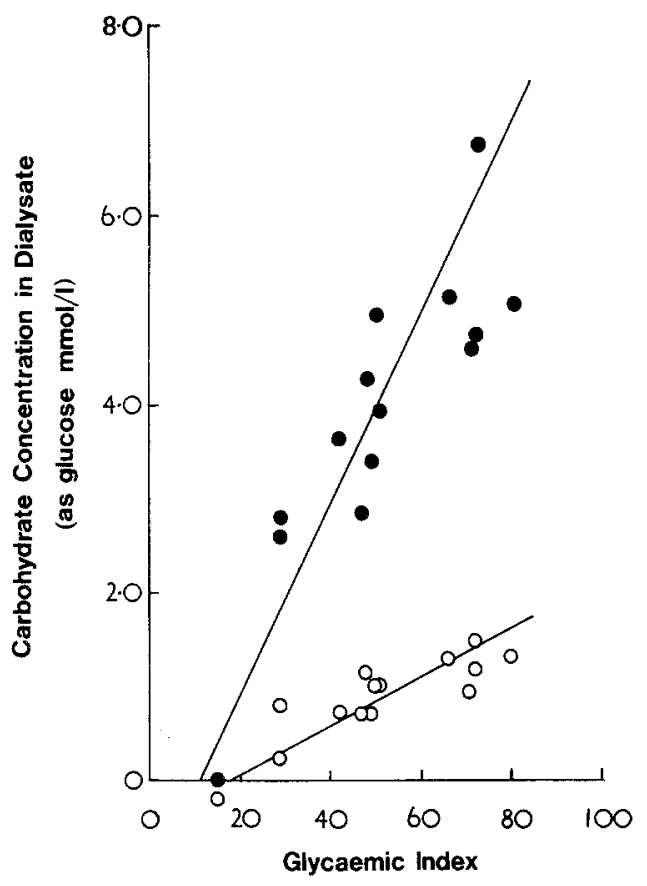

Fig. 1. The correlation between the concentration of carbohydrate liberated in vitro at $1(\mathrm{O})$ und $5 \mathrm{~h}(\mathbf{O})$ and the glycaemic index of 14 foods. The carbohydrate concentration in the dialysate was calculated as the difference between the total sugars, estimated as glucose, liberated from the digestive juice-food mixture minus that liberated from the digestive juice blank. Significant relationships were seen at $1 \mathrm{~h}(r=0.8627, p<0.001)$ and $5 \mathrm{~h}(r=0.8618, p<0.001)$

\section{Results}

Studies in vitro: When the results were calculated as the difference in dialysate values after food plus digestive juices and after digestive juices alone, the mean dialysate carbohydrate concentration for all 14 foods (measured as glucose after hydrolysis) increased from $0.88 \mathrm{mmol} / 1$ at $1 \mathrm{~h}$ to $3.91 \mathrm{mmol} / \mathrm{l}$ at $5 \mathrm{~h}$ (Table 2). This represented digestion of $27 \%$ of the original $2 \mathrm{~g}$ carbohydrate portions used. Only $0.46 \mathrm{mmol} / 1(12 \%)$ could be accounted for as glucose (Table 2) and the remaining $88 \%$ must therefore be made up of maltose, maltitriose and $\propto$-limit dextrins.

If the carbohydrate liberated was calculated from the difference in dialysate values between the food with unboiled and the food with boiled (inactivated) digestive juice, then higher values were obtained at least for glucose (Table 2). This can be explained by the ability of the foods to trap added glucose and maltose (Table 3). Glucose, already present in the Lundh juice, was trapped by the food. This produced artificially low values for the carbohydrate liberated by digestion if calculated without using the value for the boiled digestive juice and food mixture as the blank.
There was a highly significant mean trapping effect by the 14 foods for both glucose $(28 \pm 3 \%, p<$ $0.001)$ and maltose $(19 \pm 6 \%, p<0.01$; Table 3$)$. The lower mean value for maltose trapping was due largely to the apparent negative trapping action of sweet potatoes and bread (Table 3). They produced this effect due to the liberation of their own free sugars and so made it impossible to assess the proportion of added maltose trapped in this system. Nevertheless, for the majority of the other foods, the glucose was similar to the maltose trapping factor.

Using the trapping factors for glucose and maltose, the total amount of carbohydrate digested, including both that appearing in the dialysate and that digested but trapped within the dialysis bag, was $9 \%$ at $1 \mathrm{~h}$ and $36 \%$ at $5 \mathrm{~h}$. As already mentioned, the values for bread and sweet potatoes are likely to be underestimates.

Of the individual foods, the leguminous seeds were different from the eight grain products in liberating significantly less carbohydrate, measured as glucose, into the dialysate both at $1 \mathrm{~h}$ by $63 \%(p<0.01)$ and $5 \mathrm{~h}$ by $56 \%(p<0.01)$. In addition, the estimated total carbohydrate digested was $43 \%$ less than the grains at $5 \mathrm{~h}(p<0.01)$.

Studies in vivo: The blood glucose data have been reported more fully elsewhere [14]. Table 4 shows the mean glucose area of the foods, the mean $50 \mathrm{~g}$ GTT glucose area of the subjects who tested the food and the glycaemic index. All the foods, except instant mashed potato, produced significantly smaller blood glucose responses than did glucose itself (mean: $52 \pm$ $5 \%, p<0.001)$. Again, the mean value for the legumes as a class was significantly below the grains $(49 \%, p<$ 0.01 ) being $30 \%$ that of glucose.

Relationship of findings in vitro to in vivo: Both the amount of substrate liberated at 1 and $5 \mathrm{~h}$ (Fig. 1) and the percentage of carbohydrate digested related significantly to glycaemic index $(r=0.8627$ and 0.8618 , $p<0.001$, and 0.702 and $0.739, p<0.01$, respectively). There were also relationships of lesser significance between the glycaemic index and the glucose trapping effect $(r=0.5558, p<0.05)$, between the glycaemic index and the dietary fibre content of the food $(r=0.6198, p<0.02)$ and between glucose trapping and dietary fibre $(r=0.5952, p<0.05)$.

\section{Discussion}

Recent interest in gastrointestinal factors which influence the post-prandial rise in peripheral blood glucose has emphasized the importance of the rate of 
gastric emptying $[11,12,19]$. The viscous forms of dietary fibre, guar and pectin, have been shown to flatten the blood glucose response following oral glucose tolerance tests [20], and it has been suggested that the effect of these substances is the direct result of their ability to decrease the rate of gastric emptying $[11,12,19]$.

Nevertheless, indirect evidence involving alteration of food form [21,22] and more recently direct evidence from studies on gastrointestinal motility [23] and absorption $[24,25]$ indicate that small intestinal events may be of major importance in determining the glycaemic response to a food.

The current studies show that different carbohydrate foods also vary in the rate at which they release their products of digestion and that the rate of digestion bears a significant relationship to the degree to which they raise the blood glucose. Whether this is due to the nature of the food carbohydrate source is not clear. It has been maintained by Dahlqvist and Borgstrom that digestion by $\propto$-amylase is not ratelimiting for absorption in vivo [26]. Both salivary and pancreatic juice contain two enzymes capable of splitting the 1,4 linkages of starch [27]. Thus, amylose, the straight chain ( $\propto-1,4$ glucose polymer) component of starch is broken down predominantly to maltose and maltotriose and a small amount of glucose, while amylopectin, the branched chain starch, containing 1 , 6 glucose linkages, is also broken down into oligo-1, 6glycosides consisting of 4 glucose units or more $(\propto-$ limit dextrins). These sugars and oligosaccharides are then available for hydrolysis by the brush border enzymes and are absorbed as glucose. In the system used here, sugars and oligosaccharides smaller than the mean pore diameter $(24 \AA)$ will diffuse through the dialysis membrane to be measured as the products of carbohydrate digestion.

Attention has been drawn to the proportion of carbohydrate liberated as glucose during digestion. A smaller proportion of glucose in the dialysate might have indicated a more branched starch molecule and it has been suggested that this could be a factor in reducing the rate of digestion. However, no relation was seen here between the percentage of carbohydrate liberated as glucose and the total amount of carbohydrate digested in $5 \mathrm{~h}$.

There was a significant relationship between glucose trapping by the food and the percentage carbohydrate digested at $5 \mathrm{~h}(r=0.6176 p<0.02)$. Trapping was most marked in the case of soya beans which could slow the outward diffusion of sugars from within the dialysis bag by as much as 50\%-60\% (Table 2).

The legumes were remarkably slow in liberating their carbohydrate products of digestion. Although in the case of soya beans this may in part have been due to the trapping of sugars, it is also possible that some foods (beans in particular), may contain inhibitors of carbohydrate digestion. An inhibitor of amylase activity has been isolated both from wheat [28] and from beans [29] and, though most is destroyed by cooking, some activity may have remained in the leguminous seeds.

Many factors may therefore influence the initial digestion of foods. Once digested, $75 \%$ of the resulting sugars have been shown to be absorbed in the proximal $70 \mathrm{~cm}$ of small intestine [27]. Assuming a small intestinal length of 6-7 m, this may allow very efficient digestion and absorption of even relatively slowly absorbed foods. Such differences in rate of digestion are indicated in this study where at $5 \mathrm{~h}$ as much as $50 \%$ to as little as $4 \%$ of the food were digested in vitro.

Not only may the slow release of substrate in the gastrointestinal tract be beneficial to those with impaired carbohydrate handling in allowing uptake of glucose without elevating peripheral blood levels but, depending on where in the small intestine the substrate is absorbed, it may also provoke a very different gut endocrine response. This in turn may result in the long term adaptive changes associated with a progressive improvement in glucose tolerance and insulin requirement as seen in both normal [30] and diabetic subjects $[2,3,9]$ taking fibre supplements or high fibre diets.

It is not suggested that the rate of digestion of a food is the only factor likely to affect the peripheral blood glucose profile. Many carbohydrate foods contain free sugars which are liberated readily without digestion. It has been suggested that sugars form about $30 \%$ of carbohydrate intake in a Western diet and constitute $15 \%$ of the glucose units absorbed [27]. This point is illustrated by sweet potatoes which by $5 \mathrm{~h}$ liberated $4.3 \mathrm{mmol} / 1$ carbohydrate (estimated as glucose, Table 3 ), of which $43 \%$ was produced by enzymatic digestion and $57 \%$ was liberated non-enzymatically. This large non-enzymatic liberation of sugars results from the fact that only $55 \%$ of the carbohydrate in sweet potato is starch, the rest is accounted for as free sugars [31].

We conclude that there is likely to be a positive relationship between the rate at which foods liberate their products of digestion and the degree to which they raise the blood glucose. This in turn may depend on the nature of the starch, the dietary fibre, protein and fat content, the presence of possible inhibitors of enzyme action and the availability of free sugars in the food.

The finding that the leguminous seeds were digested more slowly than the other foods is in agreement with the flatter blood glucose curves seen in studies in vivo $[32,33]$. These findings add further support to the concept that leguminous seeds may be of 
use in the diets of diabetic and hypertriglyceridaemic individuals where it is desirable to reduce post-prandial glycaemia. Further testing in vitro may allow identification of other classes of foods and food constituents which are most useful in this respect.

Acknowledgements. DJAJ has been in receipt of funds from the British Diabetic Association, the Canadian Diabetes Association, the Bickell Foundation, the Atkinson Foundation and the Natural Sciences and Engineering Research Council of Canada. RHT is a Wellcome Senior Research Fellow in Clinical Science.

\section{References}

1. Trowell HC (1975) Diabetes mellitus and obesity. In: Burkitt DP, Trowell HC (eds) Refined carbohydrate foods and fibre. Academic Press, London, pp 227-251

2. Anderson JW, Chen WJ (1979) Plant fiber: carbohydrate and lipid metabolism. Am J Clin Nutr 32: 346-363

3. Anderson JW, Ward K (1979) High-carbohydrate, high-fiber diets for insulin-treated men with diabetes mellitus. Am J Clin Nutr 32: 2312-2321

4. BrunzellJD, Learner RI, Hazzard WR, Porte D, Jr, Bierman EL (1971) Improved glucose tolerance with high carbohydrate feeding in mild diabetes. New Engl J Med 284: 521-524

5. Jenkins DJA (1979) Dietary fibre, diabetes and hyperlipidaemia. Lancet 2: 1287-1290

6. Simpson RW, MannJI, EatonJ, Moore RA, Carter R, Hockaday TDR (1979) Improved glucose control in maturity-onset diabetes treated with high-carbohydrate-modified fat diet. $\mathrm{Br}$ Med J 1: 1753-1756

7. Crapo PA, Reaven G, OlefskyJ (1977) Postprandial plasmaglucose and -insulin responses to different complex carbohydrates. Diabetes 26:1178-1183

8. Jenkins DJA, Leeds AR, Gassull MA, WoleverTMS, Goff DV, Alberti KGMM, Hockaday TDR (1976) Unabsorbable carbohydrates and diabetes: decreased post-prandial hyperglycaemia. Lancet 2: 172-174

9. Jenkins DJA, WoleverTMS, Nineham R, Taylor RH, MetzGL, Bacon S, Hockaday TDR (1978) Guar crispbread in the diabetic diet. Brit Med J 2: 1744-1746

10. Miranda PM, Horwith DL (1978) High fibre diets in the treatment of diabetes mellitus. Ann Intern Med 88:482-486

11. Leeds AR, Bolster NR, Andrews R, Truswell AS (1979) Meal viscosity, gastric emptying and glucose absorption in the rat. Proc Nutr Soc 38: 44A (Abstract)

12. HoltS, Heading RC, Carter DC, Prescott LF, Tothill P (1979) Effect of gel fibre on gastric emptying and absorption of glucose and paracetamo1. Lancet 1:636-639

13. Jenkins DJA, WoleverTMS, Taylor RH, Ghafari H, Jenkins AL, Barker H, Jenkins MJA (1980) Rate of digestion of foods and postprandial glycaemia in normal and diabetic subjects. $\mathrm{Br}$ Med J 2:14-17

14. Jenkins DJA, Wolever TMS, Taylor RH, Barker HM, Fielden H, Baldwin JM, Newman HC, Bowling AC, Goff DV (1980) Bioavailability to man of carbohydrate in foods. Proc Nutr Soc 39: 11A (Abstract)

15. Werner W, Rey HG, Wielinger $H$ (1970) Über die Eigenschaften eines Chromogens für die Blutzuckerbestimmung nach der GOD/POD Methoden. Z Analyt Chem 252: 224-227

16. Paul AA, Southgate DAT (1978) McCance and Widdowson's the composition of foods. Medical Research Council special report series no 297. Her Majesty's Stationery Office, London
17. Platt BS (1962) Tables of representative values of foods commonly used in tropical countries. Medical Research Council special report series no 302. Her Majesty's Stationery Office, London

18. Clark LC Jr (1973) A polarographic enzyme electrode for the measurement of oxidase substrates. In: Kessler M, Bruley DF, Leland CC, Lübbers DW, Silver IA, Strauss J (eds) Oxygen supply. Urban \& Schwarzenberg, Munich, pp 120-128

19. Leeds AR, Ralphs DN, Boulos P, Ebied F, Metz G, DilawariJB, Elliot A, Jenkins DJA (1978) Pectin and gastric emptying in the dumping syndrome. Proc Nutr Soc 37:23A (Abstract)

20. Jenkins DJA, Wolever TMS, Leeds AR, Gassull MA, Haisman P, Dilawari JB, Goff DV, Metz GL, Alberti KGMM (1978) Dietary fibres, fibre analogues, and glucose tolerance: importance of viscosity. Br Med J 1: 1392-1394

21. HaberGH, Heaton KW, Murphy D, Burroughs LF (1976) Depletion and disruption of dietary fibre: effects on satiety, plasma-glucose, and serum insulin. Lancet 2:679-682

22. O'Dea K, Nestel PJ, Antonoff L (1980) Physical factors influencing postprandial glucose and insulin responses to starch. Am J Clin Nutr 33:760-765

23. Thompson DG, Archer L, Benson M, Green W, Hardy R, Wingate DL (1979) Variation in the glucose tolerance test with normal changes in fasting upper gastrointestinal motility. Clin Sci 57:25P (Abstract)

24. Elsenhaus B, Süfke V, Blume R, Caspary WF (1980) The influence of carbohydrate gelling agents on rat intestinal transport of monosaccharides and neutral amino acids in vitro. Clin Sci $59: 373-380$

25. Johnson IT, Gee JM (1980) Inhibitory effect of guar gum on the intestinal absorption of glucose in vitro. Proc Nutr Soc 39: 52A (Abstract)

26. Dahlqvist A, Borgstrom B (1961) Digestion and absorption of disaccharides in man. Biochem J 81:411-418

27. Silk DBA, Dawson AM (1979) Intestinal absorption of carbohydrate and protein in man. In: Crane RK (ed) Gastrointestinal physiology III, vol19. University Park Press, Baltimore, pp 151-203

28. Puls W, KeupU (1973) Influence of an $\propto$-amylase inhibitor (BAY d 7791) on blood glucose, serum insulin and NEFA in starch loading tests in rats, dogs and man. Diabetologia 9 : 97-101

29. MarshallJJ, Lauda CM (1975) Purification and properties of Phaseolamin, an inhibitor of $\propto$-amylase from the kidney bean (Phaseolus vulgaris). J Biol Chem 250:8030-8037

30. Brodribb AGM, Humphreys DM (1976) Metabolic effects of bran in patients with diverticular disease. Br Med J 1: 424-430

31. Southgate DAT, PaulAA, Dean AC, Christie AA (1978) Free sugars in foods. J Human Nutr 32: 335-347

32. Jenkins DJA, WoleverTMS, Taylor RH, Barker H, Fielden $H$ (1980) Exceptionally low blood glucose response to dried beans: comparison with other carbohydrate foods. $\mathrm{Br} \operatorname{Med} \mathrm{J} 2$ : $578-580$

33. Jenkins DJA, Wolever TMS, Taylor RH, Barker HM, Fielden $\mathrm{H}$, Baldwin JM, Bowling AC, Newman HC, Jenkins AL, Goff DV (1981) Glycemic index of foods: a physiological basis for carbohydrate exchange. Am J Clin Nutr 34: 362-366

Received: 6 April 1981

and in revised form: 21 January 1982

David J.A. Jenkins

Department of Nutritional Sciences

Faculty of Medicine, University of Toronto

Toronto, Ontario, Canada M5S 1A8 